\title{
ANALISIS PERKEMBANGAN USAHA MIKRO KECIL MENENGAH SEBELUM DAN SESUDAH MENERIMA PEMBIAYAAN SYARIAH (STUDI PADA PT. BPRS HIKMAH WAKILAH BANDA ACEH)
}

\author{
Febrian Tri Irawan ${ }^{1}$, Ratna Mulyany ${ }^{* 2}$ \\ ${ }^{1,2}$ Program Studi Akuntansi Fakultas Ekonomi Universitas Syiah Kuala \\ e-mail: febrianfti@gmail.com ${ }^{1}$,ummuhaziq@unsyiah.ac.id ${ }^{* 2}$ \\ * Corresponding Author
}

\begin{abstract}
This study aims to examine whether there is an improvement in the profit, the number of customers, and the number of employees for Micro, Small and Medium Enterprises (MSMEs) before and after receiving shariah financing. Total of 93 respondents were selected based on purposive sampling method with a focus on MSMEs which have received shariah financing from PT. BPRS Hikmah Wakilah Banda Aceh. This research is quantitative descriptive using questionnaires to obtain data about the development of MSMEs. Data was analyzed using the Wilcoxon sign rank test. This study found there is a difference and an increase in the profit based on the test of descriptive statistic and Wilcoxon rank test. Likewise with the aspects of customers and employees, this study discovered that there is a difference and an increase in the number of customers and employees pursuant to the receip of shariah financing by the MSMEs. It implies that sharia financing plays a role in the development of MSMEs.
\end{abstract}

Keywords: MSMEs Profit, Business Development, Shariah Financing

\section{Pendahuluan}

Usaha Mikro Kecil Menengah atau kepanjangan dari UMKM adalah bagian yang paling utama dari pertumbuhan ekonomi suatu daerah dan negara (Sadi dan Henderson, 2010). UMKM menjadi pusat perhatian oleh pemerintah karena dinilai memiliki kedudukan yang substansial terhadap perekonomian Indonesia (Profil Bisnis UMKM, 2015).

Salah satu kontribusi UMKM yang berdampak pada perekonomian Indonesia yaitu, UMKM mempunyai kontribusi sebanyak $99,99 \%$ dari total keseluruhan unit usaha di Indonesia yang mencapai 55,2 juta unit (Perkembangan Data UMKM DEPKOP, 2017). Data tersebut juga menyebutkan bahwa jumlah tenaga kerja di sektor UMKM yaitu sebesar 116,67 juta pekerja $(97,02 \%)$ yang jumlahnya paling besar dibandingkan tenaga kerja lainnya. Tenaga kerja yang paling mendominasi yaitu pada usaha mikro sebanyak $89,17 \%$, sedangkan jumlah tenaga kerja pada usaha kecil dan menengah masing-masing sebanyak $4,74 \%$ dan $3,11 \%$. Kontribusi UMKM dalam perekonomian dapat menjadikan UMKM sebagai prioritas nasional dalam percepatan pembangunan yang dapat menyerap tenaga kerja dalam jumlah yang cukup banyak, dan menciptakan banyak lapangan pekerjaan sehingga berkurangnya pengangguran (Purnamasari dan Darmawan, 2017).

Namun, kontribusi UMKM dalam perekonomian Indonesia tidak membuat UMKM terlepas dari masalah. Ada beberapa permasalahan yang umum dihadapi oleh pengusaha UMKM seperti keterbatasan modal, keterbatasan teknologi, keterbatasan sumber daya manusia dengan kualitas yang baik, kesulitan mengakses informasi pasar, serta kesulitan dalam pemasaran. Dari sekian banyaknya hal yang menjadi hambatan dalam menjalankan usaha, permasalahan modal merupakan permasalahan yang paling sering terjadi sehingga hal ini menyebabkan UMKM tidak bisa mengembangkan usahanya dengan baik (Sudarno, 2011).

Akibat dari permasalahan permodalan tersebut, sekarang ini banyak lembaga keuangan yang berlomba-lomba untuk dapat memberikan kredit produktif kepada UMKM sebagai salah satu bentuk 
dalam meningkatkan perekonomian Negara (Mochtar, 2019). Permodalan dalam sebuah usaha merupakan salah satu elemen penting dalam mempertahankan laju usaha dengan suatu tujuan untuk mencapai tingkat pendapatan yang ideal. Masalah permodalan yang dihadapi UMKM dapat diatasi dengan adanya sebuah lembaga keuangan untuk menyalurkan permodalan atau pembiayaan kepada usaha-usaha yang membutuhkan seperti UMKM. Lembaga - lembaga keuangan ini tidak hanya dari lembaga konvensional tetapi juga lembaga-lembaga keuangan syariah (www.kompasiana.com, 2018).

Untuk memenuhi kebutuhan masyarakat tersebut, maka dalam sistem perbankan nasional terdapat bank syariah yang salah satu jenisnya adalah Bank Pembiayaan Rakyat Syariah (BPRS). Keberadaan BPRS dimaksudkan untuk dapat memberikan layanan perbankan secara cepat, mudah, dan sederhana kepada masyarakat khususnya pengusaha mikro, kecil, menengah baik di perdesaan maupun perkotaan (Peraturan OJK No. 3 /POJK.03/2016).

Salah satu BPRS yang terdapat di Kota Banda Aceh adalah BPRS Hikmah Wakilah. BPRS Hikmah Wakilah merupakan BPRS yang berhasil dalam menyalurkan pembiayaan kepada nasabah dan merupakan BPRS yang tergolong paling besar di Kota Banda Aceh apabila dilihat dari jumlah aset. Hingga Desember 2018, aset BPRS Hikmah Wakilah mencapai Rp 91,86 miliar atau meningkat sebesar 25 persen dibanding periode yang tahun 2017 sebesar Rp 73,55 miliar, sedangkan total aset saat berlangsungnya Rapat Umum Pemegang Saham (RUPS) tahun buku 2018 mencapai angka Rp 101 miliar. Pertumbuhan aset mayoritas dipengaruhi oleh semakin meningkatnya kepercayaan masyarakat yang menyimpan dana dan melakukan pembiayaan syariah di BPRS Hikmah Wakilah

(www.acehtribunnews.com).

Untuk mengukur apakah sebuah usaha mengalami perkembangan atau peningkatan yang baik, maka hal itu dapat dilihat melalui adanya pertambahan laba, pertumbuhan volume, tenaga kerja, dan pengembalian investasi (Jennings dan Beaver, 1997). Kim dan Choi (1994), Lee dan Miller (1996), Luo (1999), Miles et al., (2000), Hadjimanolis, (2000) dalam Camelia dan Ridlwan (2013), untuk mengukur kinerja UMKM dapat dilihat dan diukur dengan memperhatikan beberapa hal seperti peningkatan pendapatan, peningkatan penjualan, peningkatan pangsa pasar, dan peningkatan jumlah karyawan.

Salah satu cara untuk dapat mengukur perkembangan UMKM dapat dilihat dari adanya perbedaan sebelum dan sesudah menggunakan pembiayaan syariah. Apabila terdapat perkembangan UMKM sesudah menggunakan pembiayaan syariah berarti penggunaan pembiayaan tersebut berhasil. Apabila sesudah penggunaan pembiayaan tidak terjadi perkembangan berarti pembiayaan tersebut belum berhasil (Prayogi \& Siregar, 2017).

Setelah mendapatkan pembiayaan syariah umumnya usaha akan mengalami perkembangan, akan tetapi tidak semua usaha yang mendapatkan pembiayaan syariah akan mengalami perkembangan. Hal ini dapat dibuktikan dari beberapa hasil penelitian yang telah dilakukan sebelumnya bahwa dalam penelitian Tunas et al., (2014) menunjukkan bahwa pembiayaan mikro syariah berpengaruh positif terhadap perkembangan usaha UMKM yang dapat dilihat dari perkembangan omzet dengan peningkatan omzet usaha. Faktor- faktor yang memengaruhi nilai perkembangan omzet adalah frekuensi pembiayaan, lama usaha, dan jumlah pembiayaan.

Prayogi \& Siregar (2017) dalam penelitiannya menunjukkan bahwa pembiayaan mikro syariah berpengaruh signifikan terhadap tingkat perkembangan UMKM, sedangkan penelitian Widagdo dan Qomar (2015) menunjukkan bahwa variabel pembiayaan murabahah berpengaruh positif dan signifikan terhadap perkembangan usaha mikro, akan tetapi variabel pembiayaan musyarakah tidak berpengaruh positif dan tidak signifikan terhadap perkembangan usaha mikro. Prastiawati dan Darma (2016) menunjukkan bahwa pembiayaan BMT pada pedagang pasar tradisional yang menjadi anggota BMT di Bantul, tidak berpengaruh signifikan terhadap perkembangan usahanya dan peningkatan kesejahteraannya.

Perbedaan hasil penelitian tersebut membuat peneliti ingin mengetahui bagaimana perkembangan UMKM dengan menggunakan indikator jumlah laba, jumlah konsumen, dan jumlah tenaga kerja sebelum dan sesudah mendapatkan pembiayaan syariah pada PT. BPRS Hikmah Wakilah Banda Aceh. 


\section{Tinjauan Pustaka}

\section{Pembiayaan Syariah}

Pembiayaan ialah pemberian berupa uang yang dilakukan atas dasar perihal sepakat yang dilakukan oleh dua pihak antara pemilik modal dan penerima modal dengan syarat pengembalian pembiayaan yang harus dilakukan secara berkala dalam waktu yang ditetapkan sesuai dengan perjanjian (Kasmir, 2014:85). Fasilitas pembiayaan banyak dilakukan oleh perbankan dan menjadi fungsi yang wajib dilaksanakan oleh perbankan sebagai salah satu produk yang sering dilakukan guna untuk memenuhi kebutuhan masyarakat yang butuh akan sebuah permodalan (Antonio, 2011:160). Pembiayaan syariah adalah kegiatan memberikan pendanaan oleh bank kepada nasabah yang membutuhkan bantuan modal dengan tanpa adanya pemberian uang tambahan karena berlandaskan pada prinsip syariah. (Muhammad, 2005:183).

Pembiayaan syariah dilakukan dengan asas kepercayaan karena memberikan sebuah pembiayaan sama dengan memberikan sebuah kepercayaan. Penerima modal atau pembiayaan harus bisa dipercaya sebagai salah satu tujuan agar pembiayaan tersebut dapat berjalan sesuai dengan yang direncanakan dan diharapkan pembiayaan tersebut dapat dikembalikan tepat waktu (Ali, 2008:46). Unsur-unsur dalam pembiayaan syariah adalah kepercayaan, kesepakatan, jangka waktu, dan risiko (Kasmir, 2014:114).

\section{Jenis Pembiayaan Syariah Murabahah}

Murbahah yaitu penjualan barang yang dilakukan oleh bank kepada pembeli dengan sistem penjualan memberikan informasi harga pembelian barang (modal) dan memberikan informasi jumlah laba yang akan diambil oleh pihak bank (PSAK 102). Murabahah ialah akad yang dilakukan secara transparan dengan sistem jual beli seperti pada umumnya akan tetapi dengan berlandaskan pada prinsip syariah. Murabahah dilakukan oleh bank kepada nasabah (pembeli) dengan menyebutkan jumlah seluruh harga pokok sebuah barang ditambah dengan persentase laba yang diperoleh bank (Nawawi, 2012:91).

Pembiayaan murabahah memiliki beberapa jenis yaitu murabahah dengan pesanan dan murabahah tanpa pesanan. Murabahah dengan pesanan dapat diartikan apabila pembeli (nasabah) ingin membeli barang yang diinginkan, lalu pihak bank akan memesan barang sesuai permintaan pembeli kepada pihak lain. Sedangkan murabahah tanpa pesanan dapat diartikan apabila pembeli (nasabah) ingin membeli barang yang telah disediakan langsung oleh pihak bank karena pada murabahah jenis ini bank telah menyediakan stok barang yang akan dijual oleh bank (Nurhayati dan Wasilah, 2015:177).

\section{Mudharabah}

Mudharabah adalah akad bagi hasil diantara dua pihak yang memiliki sejumlah modal dan pihak yang ingin menjalankan kegiatan usaha dari modal yang diberikan dengan pembagian keuntungan diterima oleh kedua belah pihak sesuai dengan nisbah yang disepakati bersama pada saat perjanjian dimuka (Friyanto, 2013). Pengertian mudharabah berdasarkan PSAK 105 adalah akad yang dilakukan secara bersama-sama antara pihak yang memerlukan modal untuk menjalankan kegiatan usaha, dan pihak yang memiliki modal lebih sebagai mitra pasif yang mengawasi kegiatan usaha, yang keuntungan dan kerugiannya pada kegiatan usaha akan ditanggung sesuai dengan kesepakatan.

Mudharabah diklasifikasikan menjadi tiga bentuk yaitu mudharabah mutlaqah, mudharabah muqayyadah, dan mudharabah musytarakah. Mudharabah mutlaqah yaitu kebebasan yang diberikan oleh pemilik modal kepada pengelola modal untuk memilih jenis usaha yang akan dilakukan berdasarkan kemampuan pengelola. Mudharabah muqayyadah yaitu pemilik modal tidak memberikan kewenangan kepada pengelola karena perencanaan usaha diatur sepenuhnya oleh pemilik modal seperti perencanaan jenis usaha, lokasi dibuatnya usaha, bagaimana kegiatan usaha akan dijalankan, dan lainnya sesuai dengan perintah pemilik modal. Mudharabah musytarakah yiatu pengelola modal ikut serta dalam menyalurkan permodalan dalam sebuah kontrak kerjasama, mudharabah jenis ini sebagai bentuk percampuran antara mudharabah mutlaqah dan mudharabah muqqayadah (Nurhayati dan Wasilah, 2015:128).

\section{Musyarakah}

Musyarakah ialah akad kerjasama dengan prinsip bagi hasil dengan ketentuan penyertaan modal 
secara bersama dan kerugian dibagi berdasarkan persentase kontribusi (PSAK 106). Pengertian musyarakah menurut Antonio (2012:90) merupakan akad yang menerapkan sistem penanaman modal bersama oleh beberapa orang yang memiliki modal dengan tujuan untuk membuka suatu usaha bersama, dikelola secara bersama, yang menganut sistem kontribusi jika terjadi keuntungan dan kerugian.

Jenis musyarakah dibagi menjadi dua bentuk diantarnya yaitu: Musyarakah permanen, yaitu musyarakah dengan perjanjian di awal menggunakan kontribusi modal bersama, hingga pada akhir akad usaha tersebut masih menjadi milik bersama. Musyarakah menurun atau musyarakah mutaqanisah, yaitu musyarkah dengan perjanjian di awal menggunakan modal kontribusi bersama antara beberapa pihak, akan tetapi seiring berjalannya usaha, modal musyarakah akan beralih kepada satu pihak (Nurhayati dan Wasilah, 2015: 154).

\section{Usaha Mikro Kecil dan Menengah}

\section{Definisi UMKM menurut Kementerian}

Koperasi dan UMKM adalah usaha yang berskala kecil, bersifat

padat karya yang melibatkan banyak aktivitas ekonomi dan bisnis dari sudut pandang teknologi, manajemen, investasi, dan hak lindung usaha. Untuk menentukan bagaimana perbedaan jenis usaha baik dari usaha mikro, kecil, maupun menengah, maka hal tersebut dapat dilihat pada UU No 20 Tahun 2008 Pasal 6 yang telah membagi karakteristik UMKM seperti berikut:

a) Kriteria usaha mikro

Jumlah asset bersih maksimal sebanyak Rp50.000.000 (lima puluh juta rupiah) tidak ditambah oleh tanah dan bangunan didirikannya usaha dan mempunyai pendapatan penjualan per tahun maksimal Rp 300.000 .000 (tiga ratus juta rupiah).

b) Kriteria usaha kecil

Jumlah aset bersih lebih besar dari Rp 50.000.000 (lima puluh juta rupiah) dan paling maksimal Rp300.000.000 (tiga ratus juta rupiah) tidak ditambah oleh tanah dan bangunan didirikannya usaha dan mempunyai pendapatan penjualan per tahun lebih besar dari Rp 300.000.000 (tiga ratus juta rupiah) dan maksimal sebanyak $\mathrm{Rp}$ 2.500.000.000 (dua miliar lima ratus juta rupiah). c) Kriteria usaha menengah

Jumlah aset bersih lebih besar dari Rp 500.000.000 (lima ratus juta rupiah) dan paling maksimal Rp10.000.000.000 (sepuluh miliar rupiah) tidak ditambah oleh tanah dan bangunan didirikannya usaha dan mempunyai pendapatan penjualan per tahun lebih besar dari $\mathrm{Rp}$ 2.500.000.000 (dua miliar lima ratus juta rupiah) dan maksimal sebanyak Rp 50.000.000.000 (lima puluh miliar rupiah).

\section{Bank Pembiayaan Rakyat Syariah}

Bank Perkreditan Rakyat Syariah (BPRS) adalah bank yang berfungsi sebagai pemberi pembiayaan syariah kepada nasabah yang membutuhkan pembiayaan berbasis syariah yang kinerjanya berlandaskan pada konsep syariah (Pasal 1 UU No. 21 Tahun 2008). BPRS sebagai salah satu lembaga penyedia modal berbasis syariah memiliki tujuan yang berperan aktif untuk menunjang perekonomian di indonesia yang dapat menjadikan ekonomi umat islam menjadi lebih sejahtera, memberikan perluasan lapangan pekerjaan, membentuk sikap persaudaraan dari aktifitas ekonomi masyarakat dengan pencapaian untuk menambah pendapatan per kapita untuk memperoleh kelayakan hidup yang tercukupi, dan melancarkan perputaran aktifitas ekonomi (Sudarsono, 2003:85).

BPRS juga memiliki fungsi yang tidak hanya menyalurkan pembiayaan syariah kepada masyarakat, akan tetapi BPRS juga menyediakan fasilitas penyimpanan yang diberikan kepada nasabah dengan berpedoman pada syariah (Muchtar et al., 2016:101). BPRS memiliki kegiatan usaha yang telah diatur di dalam UU No 21 tahun 2008 dimana kegiatan tersebut meliputi penyimpanan dana dari nasabah yang dapat berupa titipan, penyaluran dana kepada nasabah, dan penyediaan berbagai produk pembiayaan syariah.

\section{Perkembangan Usaha}

Perkembangan adalah proses secara bertahap dan mengarah kepada kemajuan dalam peningkatan kemampuan secara konsep, teoretis, teknis, dan moral pribadi berdasarkan keperluan akan sebuah pekerjaan atau tingkatan golongan yang dapat dicapai dari pelatihan dan pendidikan (Hasibuan, 2007:69). Perkembangan usaha di dalam Kamus Besar Bahasa Indonesia (KBBI) adalah sebuah tahap yang berjalan 
ke arah yang lebih maju untuk mengubah usaha yang lebih baik dari sebelumnya dengan sebuah target pencapaian usaha yang sukses dan meraih untung lebih banyak dari sebelumnya. Perkembangan usaha juga diartikan sebagai saat dimana omzet penjualan mengalami peningkatan (Chandra, 2000).

Perkembangan usaha dapat dicapai apabila usaha yang dijalankan sedalan dalam proses perbaikan dan terdapat potensi usaha yang terjamin untuk menjadi sukses dan bertumbuh di kemudian hari (Sartono, 2001:122). Secara khusus perkembangan usaha dapat diukur melalui jumlah pendapatan, peningkatan volume penjualan, jumlah konsumen, dan jumlah tenaga kerja (Kim dan Choi (1994), Lee dan Miller, (1996), Luo (1999), Miles et al., (2000), Hadjimanolis, (2000) dalam Camelia dan Ridlwan (2013).

Perkembangan UMKM memiliki tujuan untuk membuat masyarakat ekonomi memiliki kompetensi dalam persaingan usaha dan meningkatkan tindakan yang lebih produktif dengan maksud untuk meningkatkan penyesuaian diri oleh kebutuhan pasar, pendayagunaan inovasi dan penggunaan teknologi (Afifuddin, 2010:180).

Perkembangan UMKM adalah sebuah tanggungjawab yang harus ditanggung bersama oleh masyarakat dan pemerintah. Agar bisa memahami masalah yang sebenarnya terjadi terhadap UMKM, maka perlu dilakukannya sebuah tindakan seperti pembentukan usaha yang kondusif, pemberian modal usaha, pemberian hak lindung usaha, pelaksanaan pelatihan, pembinaan pemasaran yang baik, dan perlakuan kerjasama yang sesuai (Hafsah 2004:4344).

\section{Metode Penelitian \\ Desain Penelitian}

Sifat studi ini bagian dari studi deskriptif dengan jenis penelitian kuantitatif deskriptif. Penelitian ini termasuk dalam intervensi minimal karena peneliti tidak ikut campur tangan dalam memengaruhi perkembangan usaha nasabah. Sifat studi bersifat tidak diatur yang berarti penelitian ini dilakukan di lingkungan secara alami dan dijalankan secara normal. Unit analisis dalam merujuk kepada individu yaitu nasabah pada PT. BPRS Hikmah Wakilah yang melakukan pembiayaan syariah untuk menjalankan sebuah UMKM. Horizon waktu yang merupakan one- shot atau cross-sectional karena peneliti hanya butuh satu kali dalam pengumpulan datanya.

\section{Populasi dan Sampel}

Populasi pada penelitian ini yaitu semua nasabah yang mendapatkan pembiayaan syariah pada PT. BPRS Hikmah Wakilah Banda Aceh. Untuk mendapatkan sampel, peneliti menentukan banyaknya sampel yang akan dipilih berdasarkan teknik slovin. Populasi dalam penelitian ini sebanyak 1.243, dengan menggunakan pertimbangan $\mathrm{e}=10 \%$.

Dari pernyataan tersebut maka didapatkan jumlah sampel sebanyak berikut:

$$
n=\frac{N}{1+N e^{2}}=\frac{1.243}{1+1.243(0,1)^{2}}=\frac{1.243}{13,43}=92,5
$$

Hasil perhitungan didapatkan sebesar 92.5 yang berarti banyaknya sampel yang dapat diambil dari jumlah populasi sebanyak 92.5 nasabah atau dibulatkan menjadi 93 nasabah.

Teknik pengambilan sampel yang digunakan pada penelitian ini menggunakan teknik convenience sampling. Menurut Uma Sekaran (2017), convenience sampling adalah kumpulan informasi-informasi dari anggota-anggota populasi yang dengan setuju mau memberikan informasi tersebut. Dengan begitu, siapa saja yang setuju memberikan informasi-informasi yang dibutuhkan dengan peneliti baik bertemu secara langsung maupun tak langsung, dapat digunakan sebagai sampel pada penelitian ini bila responden tersebut cocok sebagai sumber data.

\section{Sumber dan Teknik Pengumpulan Data}

Penelitian ini menggunakan sumber data primer dalam pengumpulan data. Alat yang digunakan dalam mengumpulkan data, penelitian ini dilakukan dengan menggunakan kuesioner. Pada penelitian ini peneliti membagikan kuesioner kepada UMKM yang melakukan pembiayaan syariah pada PT. BPRS Hikmah Wakilah Banda Aceh.

\section{Metode Analisis Data dan Pengujian Hipotesis}

Untuk menganalisis data, penelitian ini menggunakan statistic deskriptif. Statistik deskriptif dilakukan dengan sejumlah analisis grafis dan statistik deskriptif membentuk komponen utama dari 
hampir semua analisis data kuantitatif (Hasan, 2003:7).

Pengujian hipotesis menggunakan Uji Wilcoxon Signed Rank Test atau disebut dengan uji pangkat berganda merupakan uji antara dua sampel berpasangan. Uji hipotesis ini boleh digunakan apabila pada data yang dikumpulkan mendapatkan hasil yang tidak normal. Pengujian hipotesis ini merupakan uji alternatif dari paired sample $\mathrm{T}$ Test (www.statistician.com). Uji Wilcoxon sign rank test mengacu pada nilai Sig. (2-tailed). Jika nilai kurang dari 0,05 dapat disimpulkan bahwa ada perbedaan yang signifikan antara kedua skor. Apabila nilai lebih dari 0,05 dapat disimpulkan bahwa tidak ada perbedaan yang signifikan antara kedua skor (Pallant, 2016).

\section{Hasil Dan Pembahasan Deskripsi Data}

Penelitian ini berdasarkan survey terhadap 93 responden yang melakukan pembiayaan syariah pada PT. BPRS Hikmah Wakilah Banda Aceh dengan jenis pembiayaan murabahah, mudharabah, dan musyarakah. Proses pengambilan data dilakukan dengan mengunjungi PT. BPRS Hikmah Wakilah dengan memberikan kuesioner kepada responden yang sedang melakukan angsuran pembiayaan syariah. Pengambilan data dilakukan selama 1 bulan lama nya

\section{Pembiayaan Syariah}

\section{Jenis Pembiayaan Syariah}

Pembiayaan syariah yang dilakukan oleh responden terdiri dari tiga jenis yaitu pembiayaan murabahah, mudharabah, dan musyarakah dengan jumlah sebagai berikut:

Tabel 4.1

Jenis Pembiayaan Syariah

\begin{tabular}{|c|c|c|}
\hline $\begin{array}{c}\text { Jenis } \\
\text { Pembiayaan }\end{array}$ & Jumlah & Persentase \\
\hline Murabahah & 70 & $75 \%$ \\
\hline Mudharabah & 12 & $13 \%$ \\
\hline Musyarakah & 11 & $12 \%$ \\
\hline Total & 93 & $100 \%$ \\
\hline
\end{tabular}

Sumber: Data diolah (2020)

Dari data tersebut dapat disimpulkan bahwa jenis pembiayaan yang paling banyak dilakukan oleh nasabah adalah pembiyaan murabahah. Jumlah responden pada jenis pembiayaan mudharabah dan musyarakah memiliki jumlah nasabah yang tergolong sedikit. Hal tersebut karena pembiayaan murabahah lebih mudah dilakukan oleh nasabah sedangkan pembiayaan mudharabah dan musyarkah lebih rumit untuk dilakukan karena persyaratan yang tergolong banyak.

\section{Jumlah Pembiayaan Syariah Yang Diperoleh Responden}

Pembiayaan yang diberikan kepada nasabah bervariasi bergantung oleh jumlah yang diajukan oleh nasabah dan kesesuaian persyaratan dari pihak bank. Jumlah pembiayaan yang dapat diberikan oleh bank kepada nasabah mencapai Rp. 500.000.000 dengan rincian sebagai berikut:

Tabel 4.2

Jumlah Pembiayaan Syariah

\begin{tabular}{c|c|c|}
\hline Jumlah Pembiayaan & Jumlah & Persentase \\
\hline $1.000 .000-4.999 .999$ & 3 & $3 \%$ \\
\hline $5.000 .000-19.999 .999$ & 28 & $30 \%$ \\
\hline $20.000 .000-49.999 .999$ & 20 & $22 \%$ \\
\hline $50.000 .000-99.999 .999$ & 15 & $16 \%$ \\
\hline$>100.000 .000$ & 27 & $29 \%$ \\
\hline Total & 93 & $100 \%$ \\
\hline
\end{tabular}

Sumber: Data diolah (2020)

Pembiayaan yang paling sedikit dilakukan nasabah pada skala 1.000.000 - 4.999.999 dengan jumlah 3 orang, hal itu terjadi karena jumlah pembiayaan pada skala tersebut masih tergolong kecil sehingga masyarakat enggan untuk melakukan pembiayaan syariah kepada pihak bank. Selanjutnya pembiayaan dengan skala 50.000.000 - 99.999.999 dilakukan oleh 15 responden, dan pembiayaan dengan skala 20.000.000 - 49.999.999 dilakukan oleh 20 responden. Pembiayaan yang paling banyak dilakukan ada pada skala 5.000.000 - 19.999.999 dan skala > $=100.000 .000$ dengan masing-masing responden berjumlah 28 dan 27.

\section{Waktu Jatuh Tempo Pembiayaan Syariah}

Pembiayaan syariah yang telah diberikan memiliki jatuh tempo yang harus dilunasi sesuai dengan kesepakatan yang telah ditentukan bersama. Jatuh tempo pembiayaan yang diberikan BPRS Hikmah wakilah mulai dari 3 bulan hingga 5 tahun dengan rincian sebagai berikut: 
Tabel 4.3

Waktu Jatuh Tempo Pembiayaan Syariah

\begin{tabular}{|c|c|c|}
\hline $\begin{array}{c}\text { Jatuh Tempo } \\
\text { (bulan) }\end{array}$ & Jumlah & Persentase \\
\hline $1-12$ & 39 & $42 \%$ \\
\hline $13-24$ & 33 & $36 \%$ \\
\hline $25-36$ & 14 & $15 \%$ \\
\hline $37-48$ & 3 & $3 \%$ \\
\hline $49-60$ & 4 & $4 \%$ \\
\hline Total & 93 & $100 \%$ \\
\hline
\end{tabular}

Sebanyak 3 responden memilih jatuh tempo pelunasan pembiayaan syariah dalam $37-48$ bulan. Sebanyak 4 responden melakukan pembiayaan syariah dengan jatuh tempo 49 - 60 bulan. Jatuh tempo pelunasan yang paling banyak dilakukan yaitu pada tempo 1 - 12 dan 13 - 24 bulan, hal tersebut karena jumlah pembiayaan yang dilakukan oleh UMKM tidak terlalu besar sehingga tidak perlu memilih jatuh tempo yang terlalu lama.

\section{Analisis Deskriptif Hasil Penelitian \\ Laba Sebelum dan Sesudah Menerima Pembiayaan Syariah}

Salah satu indikator untuk melihat apakah usaha mengalami perkembangan dapat membandingkan antara laba sebelum menerima pembiayaan syariah dan laba setelah menerima pembiayaan syariah. Berikut sajian laba sebelum menerima pembiayaan syariah:

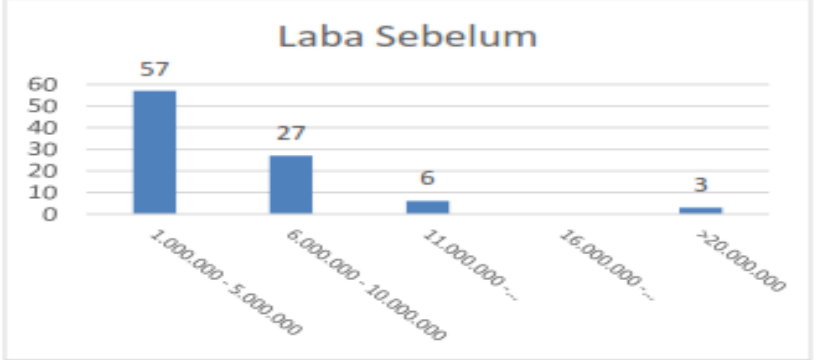

Gambar 1 Laba Sebelum Menerima Pembiyaan Syariah

Berdasarkan diagram tersebut diketahui bahwa laba penjualan responden dalam waktu satu tahun sebelum menerima pembiayaan syariah di PT. BPRS Hikmah Wakilah dalam skala laba terkecil yaitu antara 1.000.000 - 5.000.000 adalah sebanyak 57 responden. Skala laba antara 6.000 .000 10.000.000 diperoleh oleh 27 responden. Laba terbesar adalah $>20.000 .000$ sebanyak 3 responden. Laba yang paling mendominasi sebelum menerima pembiayaan syariah adalah 1.000.000 - 5.000.000.

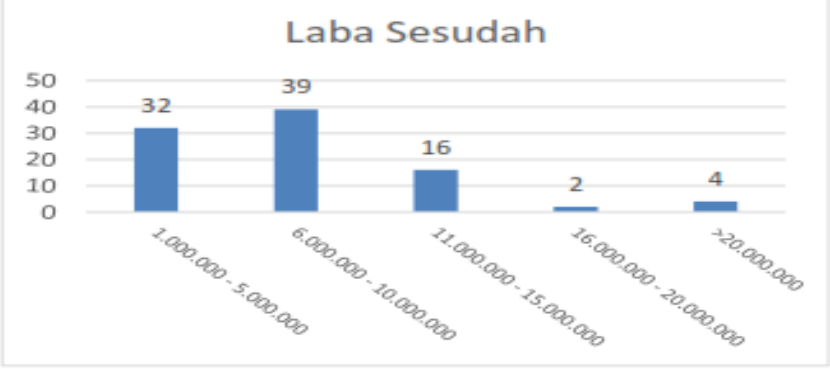

Gambar 2 Laba Sesudah Menerima Pembiayaan Syariah

Berdasarkan diagram di atas diketahui bahwa laba sesudah menerima pembiayaan syariah selama 1 tahun berjalan menunjukkan hasil yang berbeda dari laba sebelum pembiayaan. Terdapat 32 responden yang memiliki laba 1.000 .000 - 5.000.000. Laba 6.000.000 -10.000.000 berjumlah 39 responden menjadi laba yang paling mendominasi diantara skala laba lainnya. Skala laba 16.000.000 - 20.000.000 dan $>20.000 .000$ yang semula memiliki 0 dan 3 responden, setelah pembiayaan syariah mengalami perubahan menjadi 2 dan 4 responden. Perbedaan laba dari sebelum dan sesudah pembiayaan dapat dilihat pada diagram berikut ini:

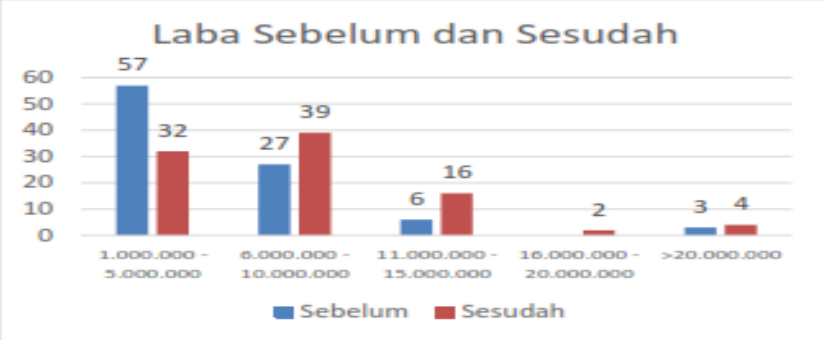

Gambar 3 Laba Sebelum dan Sesudah Menerima Pembiayaan Syariah

Berdasarkan pada diagram perbandingan laba sebelum dan sesudah menerima pembiayaan syariah dapat disimpulkan bahwa skala laba 1.000.000-5.000.000 mengalami penurunan Penurunan skala laba yang paling kecil tersebut dapat diartikan bahwa banyak responden telah mengalami peningkatan pada skala laba yang lebih tinggi. Pada laba 6.000.000-10.000.000 mengalami peningkatan dari 27 responden menjadi 39 responden, hal tersebut berarti banyak usaha yang mengalami peningkatan laba. Laba 11.000.000-15.000.000 juga mengalami peningkatan yang semula 6 responden menjadi 16 responden. Selanjutnya laba 16.000 .000 - 
20.000.000 dan laba 26.000.000 -30.000.000 yang semula 0 responden mengalami peningkatan menjadi 1 responden. Dapat disimpulkan dari beberapa skala laba tersebut, hampir semua usaha mengalami peningkatan setelah menerima pembiayaan syariah. Analisis selanjutnya dapat dilihat pada uji statistic berikut:

Tabel 3

Statistik Deskriptif Laba Sebelum dan Sesudah

\begin{tabular}{|l|l|l|l|l|}
\hline & $\mathrm{N}$ & Min & Max & Mean \\
\hline Laba Sebelum & 93 & 1.500 .000 & 35.000 .000 & $6.096 .236,56$ \\
\hline Laba Sesudah & 93 & 2.000 .000 & 50.000 .000 & $8.767 .741,94$ \\
\hline $\begin{array}{l}\text { Valid N } \\
\text { (listwise) }\end{array}$ & 93 & & & \\
\hline
\end{tabular}

Jumlah laba terkecil (minimum) yang diperoleh sebesar 1.500.000 sedangkan jumlah laba terbesar (maximum) sebesar 35.000.000. Setelah melakukan pembiayaan syariah, terjadi peningkatan laba minimum menjadi 2.000.000 dan mengalami peningkatan laba maximum menjadi 50.000.000. Apabila dilihat dari rata-rata laba (mean) sebelum melakukan pembiayaan syariah sebesar 6.096.236 dan terjadi peningkatan rata- rata laba setelah pembiayaan syariah menjadi 8.767.741.

\section{Konsumen Sebelum dan Sesudah Menerima Pembiayaan Syariah}

Jumlah konsumen pada data merupakan akumulasi konsumen selama satu bulan. Berikut adalah sajian laba sebelum menerima pembiayaan syariah:

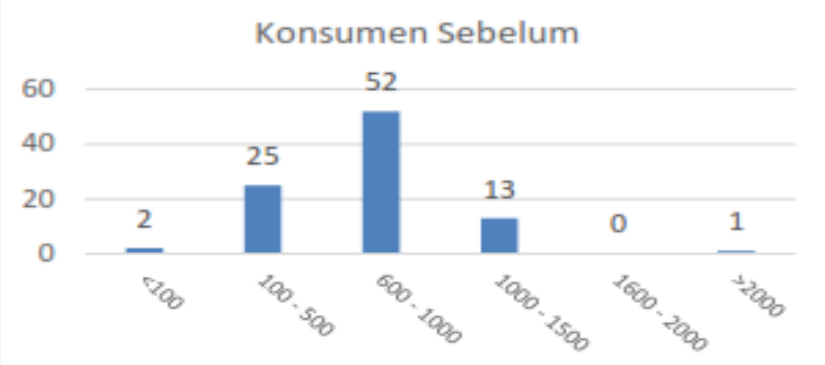

Gambar 4. Konsumen Sebelum Menerima Pembiayaan Syariah

Diagram di atas merupakan jumlah konsumen yang telah diakumulasi selama sebulan pada saat sebelum menerima pembiayaan syariah. Jumlah konsumen dalam skala $<100$ terdapat 2 responden. Terdapat 25 responden yang memiliki jumlah konsumen sebanyak 100-500 dalam sebulan.
Responden terbanyak berjumlah 52 memiliki konsumen sebanyak 600-1000 dalam sebulan. Sebanyak 13 responden dapat meraih 1000-1500 konsumen dalam jangka waktu sebulan. Tidak ada responden yang memiliki jumlah konsumen 16002000. Responden dengan jumlah konsumen paling banyak yaitu >2000 hanya dimiliki oleh 1 responden.

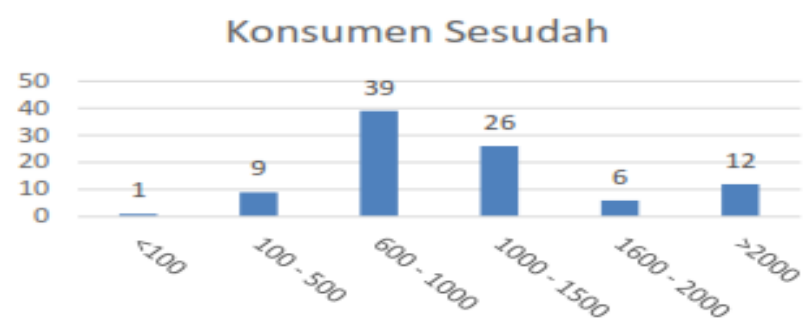

Gambar 4.5 Konsumen Sesudah Menerima Pembiayaan Syariah

Diagram di atas merupakan jumlah konsumen sesudah menerima pembiayaan syariah. Data jumlah konsumen diambil setelah 1 tahun berdirinya usaha. Jumlah konsumen >100 terjadi pada 1 responden. Sebanyak 9 responden memiliki jumlah konsumen 100-500. Responden yang paling banyak berjumlah 39 dengan jumlah konsumen 600-1000. Jumlah konsumen 1000-1500 terjadi pada 26 responden. Jumlah konsumen 1600-2000 dimiliki oleh 6 responden. Jumlah konsumen terbanyak $>2000$ terjadi pada 12 responden. Perbedaan jumlah konsumen sebelum dan sesudah menerima pembiayaan syariah dideskripsikan pada diagram berikut:

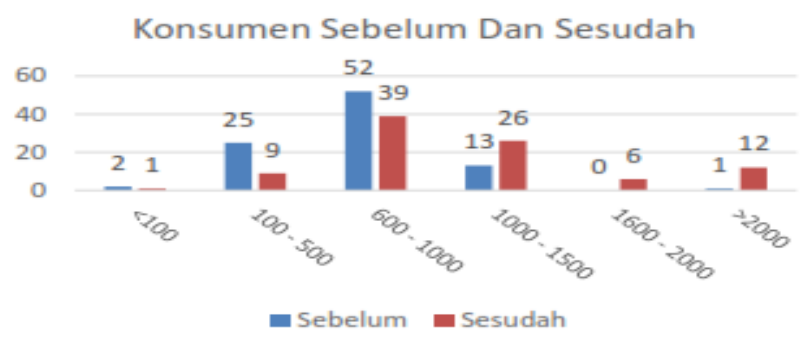

Gambar 4.6 Konsumen Sebelum dan Sesudah Menerima Pembiayaan Syariah

Perbandingan jumlah konsumen antara sebelum dan sesudah menerima pembiayaan syariah dengan jumlah konsumen $<100$ pada saat sebelum menerima pembiayaan syariah berjumlah 2 responden dan pada saat sesudah menerima pembiayaan syariah menjadi 1 responden yang berarti 1 responden mengalami peningkatan jumlah konsumen ke skala yang lebih tinggi. Jumlah konsumen pada skala 100 500 juga mengalami penurunan yang berarti banyak 
responden mengalami pertambahan konsumen pada skala yang lebih tinggi. Jumlah konsumen 600 - 1000 apabila dilihat mengalami penurunan setelah pembiayaan syariah, akan tetapi penurunan pada skala skala tersebut dapat disimpulkan bahwa banyak responden yang labanya meningkat karena pada skala 1000 - 15000 jumlahnya semakin meningkat. Jumlah konsumen 1600-2000 pada saat sebelum pembiayaan berjumlah 0 responden, setelah pembiayaan menjadi 6 responden yang berarti terjadi peningkatan konsumen. Jumlah responden $>2000$ juga mengalami peningkatan yang sangat signifikan. Analisis deskriptif lainnya dijelaskan pada uji statistik deskriptif berikut ini:

Tabel 4.6

Statistik Deskriptif Konsumen Sebelum dan Sesudah

\begin{tabular}{|l|c|c|c|c|}
\hline & N & Min & Max & Mean \\
\hline Konsumen Sebelum & 93 & 60 & 2400 & 740,32 \\
\hline Konsumen Sesudah & 93 & 60 & 3600 & $1.183,23$ \\
\hline Valid N (listwise) & 93 & & & \\
\hline
\end{tabular}

Sumber: Data diolah (2020)

Pada uji statistik deskriptif diketahui bahwa nilai minimum jumlah konsumen pada saat sebelum menerima pembiayaan sebanyak 60 konsumen. Sesudah menerima pembiayaan jumlah konsumen mengalami peningkatan menjadi 2400 konsumen. Nilai rata-rata jumlah konsumen dari 93 responden adalah 740.32 responden dalam satu bulan. Setelah menerima pembiayaan syariah jumlah konsumen minimum masih sama di angka 60 , akan tetapi jumlah konsumen maximum meningkat menjadi 3600 konsumen. Nilai rata-rata sesudah menerima pembiayaan syariah juga membuktikan hasil meningkat yaitu 1183.23.

\section{Tenaga Kerja Sebelum dan Sesudah Menerima Pembiayaan Syariah}

Apabila jumlah tenaga kerja pada suatu usaha mengalami pertambahan maka dapat dikatakan usaha mengalami perkembangan. Berikut ini adalah data tenaga kerja UMKM dari 93 responden sebelum dan sesudah menerima pembiayaan syariah dengan menggunakan uji statistik deskriptif:
Tabel 4.7

Statistik Deskriptif Tenaga Kerja Sebelum dan Sesudah

\begin{tabular}{|l|c|c|c|c|}
\hline & N & Min & Max & Mean \\
\hline Konsumen Sebelum & 93 & 1 & 6 & 1,85 \\
\hline Konsumen Sesudah & 93 & 1 & 12 & 3,14 \\
\hline Valid N (listwise) & 93 & & & \\
\hline
\end{tabular}

Sumber: Data diolah (2020)

Jumlah tenaga kerja paling sedikit sebelum menerima pembiayaan syariah adalah 1 berdasarkan nilai minimum, sedangkan jumlah tenaga kerja paling banyak sesudah menerima pembiayaan syariah ada 6 berdasarkan nilai maksimum. Setelah menerima pembiayaan syariah jumlah tenaga kerja paling sedikit masih berjumlah 1 , sedangkan jumlah tenaga kerja paling banyak meningkat menjadi 12. Apabila dilihat dari nilai rata-rata (mean) jumlah tenaga kerja sebelum menerima pembiayaan syariah adalah 1.85 , sedangkan jumlah tenaga kerja sesudah menerima pembiayaan syariah adalah 3.14. Dari hasil uji tersebut dapat disimpulkan bahwa jumlah tenaga kerja mengalami peningkatan. Perbandingan antara jumlah tenaga kerja sebelum dan sesudah menerima pembiayaan syariah berdasarkan nilai rata-rata (mean) dapat dilihat pada diagram berikut ini:

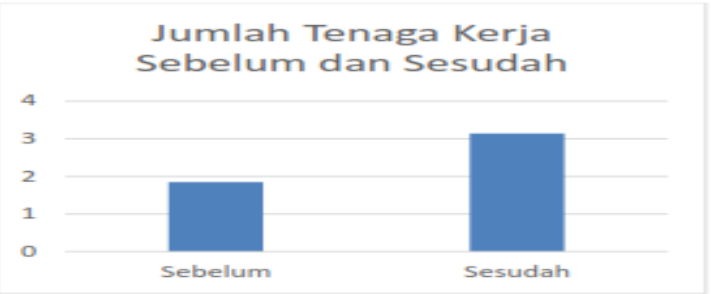

Gambar 4.7 Tenaga Kerja Sebelum dan Sesudah Menerima Pembiayaan Syariah

\section{Uji Hipotesis Wilcoxon Sign Rank Test Laba}

Uji hipotesis laba dapat disimpulkan bahwa Negative Ranks bernilai 2 yang artinya terdapat laba yang lebih rendah sebanyak 2 responden sesudah menerima pembiayaan syariah. Positive ranks berjumlah 86 yang berarti sebanyak 86 responden mengalami peningkatan laba setelah menerima pembiayaan syariah. Nilai Dari hasil uji di atas dapat disimpulkan bahwa Negative Ranks bernilai 2 yang artinya terdapat laba yang lebih rendah sebanyak 2 responden sesudah menerima pembiayaan syariah. Positive ranks berjumlah 86 yang berarti sebanyak 86 responden mengalami peningkatan laba setelah menerima pembiayaan syariah. Nilai Ties 
berjumlah 5 yang artinya terdapat 5 responden yang memiliki laba dengan jumlah yang sama sebelum dan sesudah menerima pembiayaan syariah.berjumlah 5 yang artinya terdapat 5 responden yang memiliki laba dengan jumlah yang sama sebelum dan sesudah menerima pembiayaan syariah.

Tabel 4.8

Uji Pangkat Tanda Wilcoxon Laba

\begin{tabular}{|c|c|c|c|c|}
\hline \multicolumn{5}{|c|}{ Laba } \\
\hline & & $\mathrm{N}$ & $\begin{array}{l}\text { Mean } \\
\text { Rank }\end{array}$ & $\begin{array}{c}\text { Sum } \\
\text { of } \\
\text { Ranks }\end{array}$ \\
\hline \multirow{4}{*}{$\begin{array}{c}\text { Sesudah } \\
- \\
\text { Sebelum }\end{array}$} & $\begin{array}{c}\text { Negative } \\
\text { Ranks }\end{array}$ & $2^{a}$ & 47 & 94 \\
\hline & $\begin{array}{c}\text { Positive } \\
\text { Ranks }\end{array}$ & $86^{b}$ & 44.44 & 3822 \\
\hline & Ties & $5^{c}$ & & \\
\hline & Total & 93 & & \\
\hline
\end{tabular}

Hasil uji hipotesis berdasarkan perhitungan Uji Wilcoxon Sign Rank Test, nilai $\mathrm{Z}$ yang diperoleh sebesar -7.778 dan nilai (Asymp. Sig 2 tailed) sebesar 0,000 yang berarti nilai tersebut kurang dari ukuran pada penelitian yaitu 0,05. Dari nilai tersebut dapat disimpulkan bahwa $\mathrm{H} 1$ diterima karena terdapat perbedaan antara laba sebelum menerima pembiayaan dan laba setelah menerima pembiayaan. Perbedaan tersebut menunjukkan hasil yang meningkat berdasarkan hasil uji pangkat tanda Wilcoxon. Dengan begitu maka dapat disimpulkan bahwa hasil penelitian ini sesuai dengan penelitian Sasongko (2017) bahwa terjadi peningkatan laba antara sebelum dan sesudah pembiayaan syariah yang membuat UMKM mengalami perkembangan.

Tabel 4.9

Hasil Uji Hipotesis Laba Sebelum dan Sesudah Menerima Pembiayaan Syariah

\begin{tabular}{|c|c|}
\hline \multicolumn{2}{|c|}{ Test Statistics ${ }^{\mathrm{a}}$} \\
\hline & $\begin{array}{l}\text { Laba Sesudah - Laba } \\
\text { Sebelum }\end{array}$ \\
\hline $\mathrm{Z}$ & -7.778 \\
\hline $\begin{array}{l}\text { Asymp. Sig. (2- } \\
\text { tailed) }\end{array}$ & .000 \\
\hline
\end{tabular}

\section{Konsumen}

Uji hipotesis konsumen dapat disimpulkan bahwa Negative Ranks bernilai 1 yang artinya terdapat jumlah konsumen yang lebih rendah sebanyak 1 responden sesudah menerima pembiayaan syariah. Positive ranks berjumlah 82 yang berarti sebanyak 82 responden mengalami peningkatan konsumen setelah menerima pembiayaan syariah. Nilai Ties berjumlah 10 yang artinya terdapat 10 responden yang memiliki konsumen dengan jumlah yang sama sebelum dan sesudah menerima pembiayaan syariah.

Tabel 4.10

Uji Pangkat Tanda Wilcoxon Konsumen

\begin{tabular}{|c|c|c|c|c|}
\hline \multicolumn{5}{|c|}{ Konsumen } \\
\hline & & $\mathrm{N}$ & $\begin{array}{l}\text { Mean } \\
\text { Rank }\end{array}$ & $\begin{array}{c}\text { Sum } \\
\text { of } \\
\text { Ranks }\end{array}$ \\
\hline \multirow{4}{*}{$\begin{array}{c}\text { Sesudah } \\
- \\
\text { Sebelum }\end{array}$} & $\begin{array}{c}\text { Negative } \\
\text { Ranks }\end{array}$ & $1^{a}$ & 3.00 & 3.00 \\
\hline & $\begin{array}{c}\text { Positive } \\
\text { Ranks }\end{array}$ & $82^{\mathrm{b}}$ & 42.48 & 3483 \\
\hline & Ties & $10^{\circ}$ & & \\
\hline & Total & 93 & & \\
\hline
\end{tabular}

Hasil uji hipotesis berdasarkan perhitungan Uji Wilcoxon Sign Rank Test, nilai Z yang diperoleh sebesar -7.939 dan nilai (Asymp. Sig 2 tailed) sebesar 0,000 yang berarti nilai tersebut kurang dari ukuran pada penelitian yaitu 0,05 . Dari hasil uji tersebut dapat disimpulkan bahwa $\mathrm{H} 2$ diterima karena terdapat perbedaan antara konsumen sebelum menerima pembiayaan dan konsumen setelah menerima pembiayaan. Perbedaan tersebut menunjukkan hasil yang meningkat berdasarkan hasil uji pangkat tanda Wilcoxon. Dengan begitu maka dapat disimpulkan bahwa hasil penelitian ini sesuai dengan penelitian Nurrohmah, Isnaini (2015) bahwa terjadi peningkatan konsumen antara sebelum dan sesudah pembiayaan syariah yang membuat UMKM mengalami perkembangan.

Tabel 4.11

Hasil Uji Hipotesis Konsumen Sebelum dan Sesudah Menerima Pembiayaan Syariah

\begin{tabular}{|l|r|}
\hline & \multicolumn{2}{|c|}{$\begin{array}{l}\text { Konsumen Sesudah - } \\
\text { Konsumen Sebelum }\end{array}$} \\
\hline $\mathrm{Z}$ & -7.939 \\
\hline $\begin{array}{l}\text { Asymp. Sig. (2 } \\
\text { tailed) }\end{array}$ & .000 \\
\hline
\end{tabular}




\section{Tenaga Kerja}

Uji hipotesis tenaga kerja dapat disimpulkan bahwa Negative Ranks bernilai 0 yang artinya tidak terdapat penurunan jumlah tenaga kerja sesudah menerima pembiayaan syariah. Positive ranks berjumlah 72 yang berarti sebanyak 72 responden mengalami peningkatan tenaga kerja setelah menerima pembiayaan syariah. Nilai Ties berjumlah 21 yang artinya terdapat 21 responden yang memiliki tenaga kerja dengan jumlah yang sama sebelum dan sesudah menerima pembiayaan syariah.

Tabel 4.12

Uji Pangkat Tanda Wilcoxon Tenaga Kerja

\begin{tabular}{|c|c|c|c|c|}
\hline \multicolumn{5}{|c|}{ Tenaga Kerja } \\
\hline & & $\mathrm{N}$ & $\begin{array}{l}\text { Mean } \\
\text { Rank }\end{array}$ & $\begin{array}{c}\text { Sum } \\
\text { of } \\
\text { Ranks }\end{array}$ \\
\hline \multirow{4}{*}{$\begin{array}{c}\text { Sesudah } \\
- \\
\text { Sebelum }\end{array}$} & $\begin{array}{c}\text { Negative } \\
\text { Ranks }\end{array}$ & $0^{2}$ & .00 & .00 \\
\hline & $\begin{array}{c}\text { Positive } \\
\text { Ranks }\end{array}$ & $72^{b}$ & 36.50 & 2628 \\
\hline & Ties & $21^{\circ}$ & & \\
\hline & Total & 93 & & \\
\hline
\end{tabular}

Berdasarkan perhitungan Uji Wilcoxon Sign Rank Test, nilai $Z$ yang diperoleh sebesar -7.939 dan nilai (Asymp. Sig 2 tailed) sebesar 0,000 yang berarti nilai tersebut kurang dari ukuran pada penelitian 0,05. Dari hasil uji tersebut dapat disimpulkan bahwa H3 diterima karena terdapat perbedaan antara konsumen sebelum menerima pembiayaan dan konsumen setelah menerima pembiayaan syariah. Perbedaan tersebut menunjukkan hasil yang meningkat berdasarkan hasil uji pangkat tanda Wilcoxon. Dengan begitu maka dapat disimpulkan bahwa hasil penelitian ini sesuai dengan penelitian Nurrohmah, Isnaini (2015), Sasongko (2017), dan Rahayu, Aprilia (2018) yang membuktikan bahwa UMKM mengalami perkembangan setelah menerima pembiayaan syariah.

Tabel 4.13

Hasil Uji Hipotesis Tenaga Kerja Sebelum dan Sesudah Menerima Pembiayaan Syariah

\begin{tabular}{|l|r|}
\hline \multicolumn{2}{|c|}{ Test Statistics $^{\mathrm{a}}$} \\
\hline & \multicolumn{1}{|c|}{$\begin{array}{l}\text { Tenaga Kerja Sesudah - } \\
\text { Tenaga Kerja Sebelum }\end{array}$} \\
\hline Z & -7.562 \\
\hline $\begin{array}{l}\text { Asymp. Sig. (2 } \\
\text { tailed) }\end{array}$ & .000 \\
\hline
\end{tabular}

\section{Kesimpulan, Keterbatasan, dan Saran Kesimpulan}

Berdasarkan hasil analisis data dan pembahasan yang telah dijelaskan pada bab sebelumnya, dapat disimpulkan bahwa:

1) UMKM yang menerima pembiayaan syariah dari PT. BPRS Hikmah Wakilah mengalami perkembangan usaha karena mayoritas laba sesudah mengalami peningkatan dari laba sebelum menerima pembiayaan syariah.

2) UMKM yang menerima pembiayaan syariah dari PT. BPRS Hikmah Wakilah mengalami perkembangan usaha karena mayoritas konsumen sesudah lebih banyak dari konsumen sebelum menerima pembiayaan syariah.

3) UMKM yang menerima pembiayaan syariah dari PT. BPRS Hikmah Wakilah mengalami perkembangan usaha karena mayoritas tenaga kerja sesudah lebih banyak dari tenaga kerja sebelum menerima pembiayaan syariah.

\section{Keterbatasan}

Penelitian ini memiliki keterbatasan informasi mengenai data kondisi sebelum menerima pembiayaan syariah dan sesudah menerima pembiayaan syariah karena hanya didasarkan pada pengakuan responden. Hal tersebut dilakukan karena banyak dari UMKM tidak memiliki laporan keuangan usahanya, sehingga dalam memperoleh data harus lebih berhati-hati.

\section{Saran}

Saran yang peneliti sampaikan pada saat mengumpulkan data penelitian diantaranya adalah:

1) Perlu mempertahankan dan meningkatkan peran lembaga keuangan syariah dalam mengatasi permasalahan permodalan yang dihadapi oleh UMKM.

2) Pembiayaan syariah berupa murabahah yang diberikan hendaknya digunakan sebaik mungkin untuk mengembangkan usahanya dan bukan digunakan untuk keperluan pribadi.

3) UMKM sebaiknya membuat laporan keuangan usaha agar bisa menjadi tolok ukur peningkatan usaha dan dapat memudahkan proses pengajuan pembiayaan pada lembaga keuangan.

4) Bagi peneliti selanjutnya, agar kiranya dapat menambah indikator lainnya selain daripada 
indikator yang peneliti gunakan.

\section{Daftar Pustaka}

Ali, Z. (2008). Hukum Ekonomi Syariah. Jakarta: Sinar Grafika.

Antonio, Muhammad Syafii. (2011). Bank Syariah: Dari Teori ke Praktik. Jakarta. Gema Insani

Antonio, Muhammad Syafii. (2012). Bank Syariah: Dari Teori ke Praktik. Jakarta. Gema Insani.

Camelia, D., \& Ridlwan, A. A. (2013). Peran Pembiayaan Murabahah Terhadap Perkembangan Usaha Dan Kesejahteraan Pelaku UMKM Pasar Tradisional. Jurnal Ekonomi Islam, 53(9), 1689-1699.

Chandra, G. (2002). Strategi \& Program Pemasaran. Yogyakarta: Andi Offset.

Davidsson, P., Kirchhoff, B., Hatemi-J, A., dan Gustavsson, H., (2002), "Empirical of Business Growth Factors Using Swedish Data", Journal of Small Business Management, 40 (4), pp. $332-349$.

DEPKOP. 2017. Perkembangan Data UMKM. Dewan Syariah Nasional, Fatwa Dewan Syariah Nasional No. 08/DSN-MUI/VI/2000, 2000

Effendi, J., \& Wardani, D. (2016). Debt Financing dan Dampaknya terhadap Perkembangan Usaha Mikro di Bogor. Jurnal Al-Muzara'ah, 4(2), 110-126.

Ernita, D., Amar, S., \& Soyofyan, E. (2013). Analisis Pertumbuhan Ekonomi, Investasi, Dan Konsumsi Di Indonesia. Jurnal Kajian Ekonomi, I(02), 176-193.

Friyanto. (2013). Pembiayaan Mudharabah, Risiko Dan

Penanganannya (Studi Kasus pada Bank BTN Kantor Cabang Syariah Malang). Jurnal Manajemen Dan Kewirausahaan, 15(2), 113-122. Ghozali, Imam. (2006). Aplikasi Analisis Multivariate dengan Program SPSS. Semarang: Badan Penerbit Universitas Diponegoro.

Hafsah, M.Jafar. (2004). Upaya Pengembangan UsahaKecil dan Menengah (UKM). Infokop Nomor 25 Tahun XX.

Hasan, Iqbal. (2003). Pokok-pokok Materi Statistik 1 (Statistik Deskriptif). Jakarta: PT Bumi Aksara.

Hasibuan, Malayu S.P (2007). Manajemen Sumber Daya Manusia Perusahaan. Bandung: PT. Bumi Aksa.

Hidayat, Anwar. Tutorial Cara Uji Wilcoxon Signed Rank Test. Melalui <https://www.statistikian.com/2014/07/tutorialuji-wilcoxon-signed-rank test.html>[10/11/19]

Husna, Mawaddatul. Aset Bank Hikmah Wakilah Tembus Rp 100 M. Melalui https://aceh.tribunnews.com/2019/03/21/aset-

bank-hikmah-wakilah-tembus-rp-100-m [27/01/20]

Ikatan Akuntansi Indonesia (2019). PSAK 102: AkuntansiMurabahah. http://iaiglobal.or.id/v03/standar-akuntansikeuangan/pernyataan-sas-68psak-102akuntansi- mudharabah [15/11/19]

Ikatan Akuntansi Indonesia (2019). PSAK 105:Akuntansi Mudharabah. http://iaiglobal.or.id/v03/standar-akuntansikeuangan/pernyataan-sas-68psak-106akuntansi- mudharabah [15/11/19]

Ikatan Akuntansi Indonesia (2019). PSAK 106: Akuntansi Musyarakah. http://iaiglobal.or.id/v03/standar-akuntansikeuangan/pernyataan-sas-68psak-106akuntansi- musyarakah [15/11/19]

Indonesia, B. (2015). Profil Bisnis Usaha Mikro, Kecil dan Menengah (UMKM). Melalui <www. bi. go. Id> [12/11/19]

Jenita. (2017). Peran Lembaga Keuangan Mikro Syariah Dalam Pemberdayaan Ekonomi Masyarakat Kecil Menengah. Jurnal Lembaga Keuangan Dan Perbankan, 2(2), 177-191

Jennings, P., \& Beaver, G. (1997). The Performance and Competitive Advantage of Small Firms: A Management Perspective. International Small Business Journal, 15(2), 63-75.

Jufri, R. A. (2017). Pengaruh Pembiayaan Murabahah Terhadap Peningkatan Kesejahteraan Usaha Miro (Studi BMT AsySyabaab Kabupaten Pinrang). Sekolah Tinggi Agama Islam Negeri.

Kasmir. (2014). Dasar-Dasar Perbankan. Jakarta: PT Raja Grafindo Persada.

KBBI. (2016). Kamus Besar Bahasa Indonesia (KBBI). <http://kbbi.web.id> [20/11/19].

Kementerian Koperasi dan UKM. Kriteria Usaha Mikro, Kecil dan Menengah Tahun 2017 - 2018. Kusuma, Artha. Peranan Lembaga Keuangan (Bank) dalam Perkembangan UKM. Melalui <https://www.kompasiana.com/arthakusuma/>[ $10 / 11 / 19]$

Mardani. (2012). Fiqh Ekonomi Syariah: Fiqh Muamalah. Jakarta: Kencana.

Mirza, Fandi Fuad. (2013). Pengaruh Perilaku Sedekah terhadap Perkembangan Usaha (Studi Kasus Peserta Komunitas Usaha Mikro Muamalat Berbasis Masjid (KUM3) di KJKS BMT An-Najah Wiradesa). Skripsi. Dipublikasikan. Semarang: Program Sarjana Universitas Islam Negeri Walisongo. 
Mochtar, H. (2019). Pengaruh Pemberian Kredit Usaha Rakyat (KUR) Terhadap Pendapatan Usaha Mikro Pada PT. Bank SULSELBAR Kantor Pusat Makasar. Bongaya Journal for Research in Management, 2(April), 1-10.

Muchtar, B., Rahmidani, R., \& Siwi, M. K. (2016). Bank dan Lembaga Keuangan Lain. Jakarta: Prenanda Media Grup.

Muhammad. (2005). Manajemen Bank Syariah. Yogyakarta: UPP AMP YKPN

Muhammad. (2009). Model-Model Akad Pembiayaan Di Bank Syariah. Yogyakarta: UII Press.

Naf'an. (2016). Pembiayaan Musyarakah dan Mudharabah. Yogyakarta: Graha Ilmu.

Nawawi, I. (2012). Fikih Muamalah Klasik dan Temporer. Bogor: Ghalia Indonesia.

Nurhayati, S., \& Wasilah. (2015). Akuntansi Syariah di Indonesia. Jakarta: Salemba Empat.

Nurmarganingsih, T. (2018). Pengaruh Penerapan Manajemen Risiko Pembiayaan, Risiko Likuiditas,

Dan Risiko Operasional Terhadap Kinerja Bpr Syariah (Studi Kasus pada BPR Syariah Provinsi Jawa Tengah dan DIY yang Terdaftar di OJK Periode 2013-2016). Universitas Muhammadiyah Purwokerto.

Nurrohmah, Isnaini. (2015). Analisis Perkembangan Usaha Mikro, Kecil dan Menengah Sebelum dan Sesudah Menerima Pembiayaan Musyarakah Pada Koperasi Jasa Keuangan Syariah BMT (Studi Kasus: BMT Beringharjo Yogyakarta). Skripsi FE UNY.

Otoritas Jasa Keuangan. Bank Perkreditan Rakyat. Melalui <https://www.ojk.go.id/id/kanal/perbankan/Pag es/ Bank-Perkreditan-Rakyat.aspx> [12/11/19]

Pallant, J. (2016). SPSS Survival Manual (Sixth). New York, USA: Mc GrawHill Education.

Prastiawati, F., \& Satya Darma, E. (2016). Peran Pembiayaan Baitul Maal Wat Tamwil Terhadap Perkembangan Usaha dan Peningkatan Kesejahteraan Anggotanya dari Sektor Mikro Pedagang Pasar Tradisional. Jurnal Akuntansi Dan Investasi, 17(2), 197-208.

Prayogi, M. A., \& Siregar, L. H. (2017). Pengaruh Pembiayaan Mikro Syariah Terhadap Tingkat Perkembangan Usaha Mikro Kecil Menengah (UMKM).17(2), 121-131.

Purnamasari, F., \& Darmawan, A. (2017). Islamic Banking and Empowerment of Small Medium Enterprise Femei. Etikonomi, 16(2), 221-230. Raharjo, Sahid. Panduan Lengkap Cara Melakukan Uji Wilcoxon dengan SPSS. Melalui
$<$ https://www.spssindonesia.com/2017/04/carauji-wilcoxon-spss.html>[10/11/19]

Rahayu, Aprilya. (2018). Analisis Perkembangan Usaha Mikro Kecil dan Menengah Sebelum dan Sesudah Menerima Pembiayaan Dari BPRS Syariah. Skripsi: Universitas Islam Negeri Sunan Kalijaga.

Republik Indoneisa. UU No. 21 Tahun 2008 Pasal 1Tentang Perbankan Syariah.

Republik Indonesia. Pasal 231 Kompilasi Hukum Ekonomi Syariah

Republik Indonesia. Peraturan OJK No. 3/POJK.03/2016.

Republik Indonesia. Undang-Undang No 20 Tahun 2008 Pasal 6 Tentang Usaha Mikro, Kecil dan Menengah (UMKM).

Republik Indonesia. Undang-Undang No. 20 Tahun 2008 Tentang Usaha Mikro Kecil dan Menengah

Republik Indonesia. Undang-Undang Nomor 13 Tahun 2003 tentang Ketenagakerjaan.

Republik Indonesia. UU No. 21 Tahun 2008 Tentang Perbankan Syariah.

Ridwan, Muhammad. (2007). Konstruksi Bank Syariah Indonesia. Yogyakarta: Pustaka SM.

Sa'diyah, M., \& Aziroh, N. (2014). Musyarakah Dalam Fiqih Dan Perbankan Syariah. Journal Stain Kudus, 2(2), 310-327.

Sadi, M. A., \& Henderson, J. C. (2011). Franchising and small medium-sized enterprises (SMEs) in industrializing economies: A Saudi Arabian perspective. Journal of Management Development, 30(4), 402-412.

Saksongko, Wahyu N. (2017). Perkembangan Usaha Mikro Kecil Dan Menengah Sebelum Dan Sesudah Menerima Pembiayaan Murabahah Pada Bmt Jannah Pucung Sragen. Skripsi: Institut Agama Islam Negeri Surakarta.

Sanusi, Anwar. (2011). Metode Penelitian Bisnis. Jakarta: Salemba Empat.

Sartono, Agus. (2001). Manajemen Keuangan Teori dan Aplikasi. Yogyakarta: BPEFYOGYAKARTA.

Sasmito, Daru L. (2019). Peran Pembiayaan Murābahạah Terhadap Pengembangan Usaha Mikro, Kecil Dan Menengah Di Ksu Bmt Artha Bina Ummat Pasar Sukodono Sidoarjo. Skripsi: Universitas Islam Negeri Sunan Ampel Surabaya.

Sekaran, U., \& Bougie, R. (2017). Metode Penelitian untuk Bisnis Pendekatan Pengembangan Keahlian. Jakarta: Salemba Empat.

Shanmugam, K. R., dan Bhaduri, S. N., 2002, Size, Age, and Firm Growth in the Indian Manufacturing Sector, Applied Economics 
Letters, 9, pp: 607-613.

Soemarso. (2010). Akuntansi Suatu Pengantar. Edisi 5. Cetakan keenam. Jakarta: Rineka Cipta.

Sri Handayani. (2012). Aspek Hukum Perlindungan Konsumen dalam Pelayanan Air Bersih pada PDAM Tirtasari Binjai. Jurnal Non Eksakta, 1(4), 2.

Sudarno. (2011). Kontribusi Usaha Mikro, Kecil Dan Menengah (UMKM) Dalam Penyerapan Tenaga Kerja Di Depok. Jurnal Ekonomi Dan Bisnis, 10(2), 139-146

Sudarsono, Heri. (2003). Bank dan Lembaga Keuangan Syariah: Deskripsi dan Ilustrasi. Yogyakarta: Ekonisia.

Sugiyono. (2016). Metode Penelitian Kuantitatif, Kualitatif, dan R\&D. Bandung: Alfabeta.

Sujarweni, V. Wiratna. (2014). Metode Penelitian: Lengkap, Praktis, dan Mudah Dipahami. Yogyakarta: Pustaka Baru Press.

Syafei, Rachmat. (2017). Fiqh Muamalah. Bandung: Pustaka Setia.

Tunas, A. P., Anggraeni, L., \& Lubis, D. (2014). Analisis Pengaruh Pembiayaan Syariah terhadap Perkembangan Usaha Mikro Kecil Menengah di Kota Depok. Al-Muzara'ah, 2(1), $1-16$.

Umam, Khotibul. (2010). Hukum Lembaga Pembiayaan. Yogyakarta: Media Pressindo. Widagdo, R., \& Qomar, N. (2014). Pengaruh Pembiayaan Murabaḥh dan Musyarakah Terhadap Perkembangan Usaha Mikro di BMT Gunung Jati. 6, 242-256. 